\title{
Contents, Vol. 23, 1984
}

Founded 1897 as 'Monatsschrift fur Psychiatrie und Neurologic’, continued 1957-1967 as ‘Psychiattria et Neurologia' Founders: C. Wernicke and Th. Ziehen. Successors: K. BonhoefTer (1912-1938), J. Klaesi (1939-1967), E. Grunthal Founded 1897
$(1953-1967)$

\section{Editor-in-Chief
H.K. Kaeser, Base}

Associate Editors C. Loeb, Genova H.-G. Mertens, Wurzburg U.K. Rinne, Turku H. vander Eecken, Ghent Editorial Board

Lditorial Board

S. Feldman, Jerusalem

S. Fuber, Bern
P. Hubern

A. Kreindler, Bucharest

H.J. Lehmann, Essen

C. Pallis, London
E. Satoyoshi, Tokyo

E. Satoyoshi, Tokyo
F. Seitelberger, Vienna

J. Ulrich, Basel
F. Vasella Bern

Advisory Board

Electromyography H.P. Ludin, Bern

Neuroendocrinology

P.O. Lundberg, Uppsala

Cerebrospinal Fluid H.B. Rieder, Basel

Electroencephalography

G. Scollo-Lavizzari, Basel

Evoked Potentials

Ophthalmology

O. Meienberg, Basel

\section{WSm}

Drug Dosage

The authors and the publisher have exerted every effort to ensure that drug selection and dosage set forth in this text are in accord with current recommendations and practice at the time of publication. However, in view of ongoing research, changes in government regulations, and the constant flow of information relaing to drug therapy and drug reactions, All rights reserved.

No part of this publication may be translated into other languages, reproduced or utilized in any form or by any means, electronic or mechanical, including photocopying recording microcopying or by any information storage and retrieval system, without permission in writing from the publisher or, in the case of photocopying, direct payment of a specified fee to the Copyright Clearance Center (see 'Information for Readers and Subscribers').

(C) Copyright 1984|by 
(Switzerland) Printed in Switzerland by Thịir AG Offsetdruck, Pratteln

Contents Vol. 23,1984

No. 1 The Anticonvulsant Effect of the Ben/.odiazepine Antagonist, Ro 15-1788: An EEG Study in 4 Cases

Scollo-Lavizzari, G 1

CAT Scan and Immunohistochemical Findings in a Case of Cerebral Thromboangitis obliterans (Buerger's Disease)

Kessler, C; Reuther, R.; Berlit, P.; Carls, C; Hofmann, W..................................................................... 7

The Palmomental Reflex. Clinical Study of 300 Cases

Marti-Vilalta, J.L.; Graus, F

The Diagnostic Value of Three Common Primitive Reflexes

Isakov, E.; Sazbon, L.; Costeff, H.; Luz, Y.; Najenson, T

Complicated Migraine in AS Hemoglobinopathy

Bussone, G.; La Mantia, L.; Boiardi, A.; Parati, E.A.; Frcdiani, F.; Testa, D ....................................... 22

Chorea and Polycythaemia

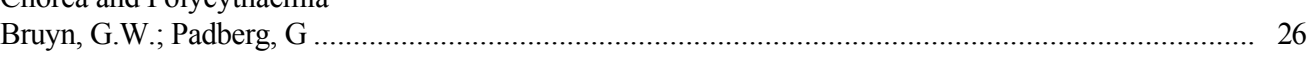

CT Findings of the Interval Form of Carbon Monoxide Poisoning Compared with Neuro-

pathological Findings

Kobayashi, K.; Isaki, K!.; Fukutani, Y.; Kurachi, M.; Eboshida, A.; Matsubara, R.;

Yamaguchi, $\mathrm{N}$

Characteristic Clinical Aspects of Parkinson Patients with Intellectual Impairment

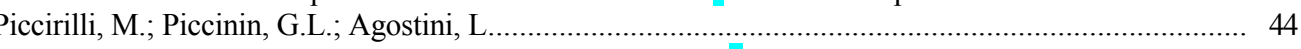

Efficacy of Baclofen in Trigeminal Neuralgia and Some Other Painful Conditions. A Clinical

Trial

Steardo, L.; Leo, A.; Marano, E

Computerized Cranial Tomography in Presymptomatic and Hepatic Form of Wilson's Disease

Dettori, P.; Rachele, M.G.; Dcmelia, L.; Pelaghi, A.E.; Nurchi, A.M.; Aromando, P.;

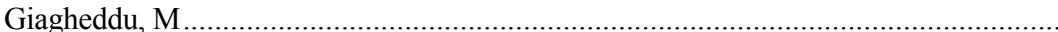
(26

Announcement

No. 2 Presence of a Tamm-Horsfall-Like Glycoprotein in the CSF of Neurology Patients. First Results

Schuller, E.; Bringuier, A.F.; Hartmann, L

Beta-Endorphin-, Leucine Enkephalin- and Methionine Enkephalin-Like Immunoreactivity

in Human Cerebrospinal Fluid. Simultaneous Determination and Relation to Neurolog

ical Disorders

Neuser, D.; Lcsch, K.P.; Stasch, J.P.; Przuntek, H...

Continuous Intraoperative EEG Monitoring during Carotid Surgery

Meneghetti, G.; Dcriu, G.P.; Saia, A.; Giaretta, D.; Ballotta, E

IV

Contents

Effect of Piracetam in Huntington's Chorea

Destee, A.; Petit, H.; Warot, P

Oculogyric Crisis Induced by Lithium Carbonate

Sandyk, R .

92

Deep Dyslexia in a Patient with Crossed Aphasia

Sartori, G.; Bruno, S.; Serena, M.; Bardin, P.

Triiodothyronine $\left(\mathrm{T}_{3}\right)$ Toxicosis with Hypokalemic Periodic Paralysis

Sunohara, N.; Satoyoshi, E...

Hyperammonemia and Valproate-Induced Alterations of the State of Consciousness. A

Report of 8 Cases

Zaccara, G.; Paganini, M.; Campostrini, R.; Arnetoli, G.; Zappoli, R.; Moroni, F. . . 104 Progressive Multifocal Leukoencephalopathy Presenting as a Single Mass Lesion

Vanneste, J.A.L.; Bellot, S.M.; Stam, F.C ………………............................................................... 113

Complete Sensory and Motor Recovery from Anterior Spinal Artery Syndrome after Sprain

of the Cervical Spine. A Case Report

Foo, D.; Rossier, A.B.; Cochran, T.P..

Cerebral Infarctions with Negative CT Scans

Johansson, $\mathrm{T}$

Investigation of the Blood-Brain Barrier for IgG in Inflammatory Syndromes of the Central 
No. $3{ }^{31} \mathrm{P}$ Nuclear Magnetic Resonance Studies of Anoxia in Aged Rat Brain

Cohen, M.M.; Kopp, S.J.; Pettegrew, J.W.; Glonek, T .........................................................................141

Distal Myopathy of Gowers: A Reappraisal

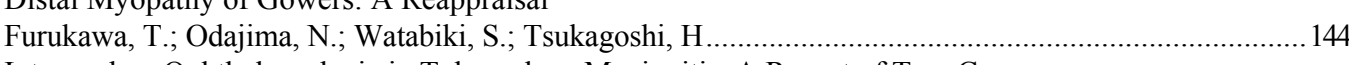

Internuclear Ophthalmoplegia in Tuberculous Meningitis. A Report of Two Cases

Sandyk, R.; Brennan, M.J.VV

Typical and Reverse Bobbing: A Case with Localizing Value

Brusa, A; Firpo, M.P.; Massa, S.; Piccardo, A.; Bronzini, E

Symptomatic Xanthogranuloma of the Third Ventricle: A Clinicopathological Report

Sandyk, R...

Cardiac Involvement in Juvenile Ceroid Lipofuscinosis of the Spielmeyer-Vogt-Sjogren

Type: Prospective Noninvasive Findings in Two Siblings

Pathological Study of the Sural Nerve in Fabry's Disease

Gemignani, F.; Marbini, A.; Bragaglia, M.M.; Govoni, E

Clofibrate-Induced Myotoxicity in Rats. Temporal Profile of Myopathology

Afifi, A.K.; Hajj, G.A.; Saad, S.; Tekian, A.; Bergman, R.A.; Bahuth, N.B.; Abourizk, N. 182 Paralysis of Upward Gaze as a Presenting Symptom of Vitamin B12 Deficiency Sandyk, R.

Cyclic AMP in the Cerebrospinal Fluid of Patients with Recent Cerebral Infarction

Mrsulja, B.B.; Djuricic, B.M.; Kostic, V.S.; Panic, M

Multiple Stroke due to Multiple Vascular Malformation of the Brain

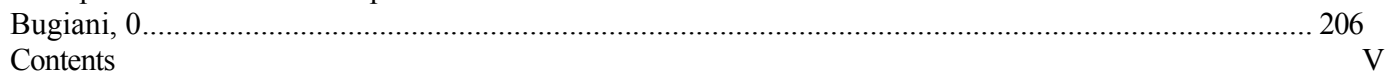

Rapidly Progressive Subacute Sclerosing Panencephalitis: An Ultrastructural and Immuno-

peroxidase Study

peroxib-Jallbut, S.;

Blink Reflex in Hemiplegia

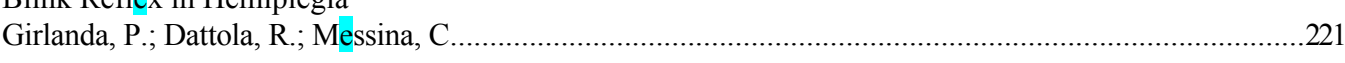

Announcements

No. 4 Cerebral Schistosomiasis Presenting as a Brain Tumor

Gjerdc, I.O.; Mork, S.; Larsen, J.L.; Huldt, G.; Skeidsvoll, H.; Aarli, J.A

Guillain-Barre Syndrome Associated with Acute Cytomegalovirus Mononucleosis Syndrome

Moz.es, B.; Pines, A.; Sayar, Y.; Kaplinsky, N.; Frankl, $0 \ldots .$.

Brain Stem Vascular Malformation Simulating a Hemorrhagic Metastasis: Report of a Case

with Pathologic Correlation

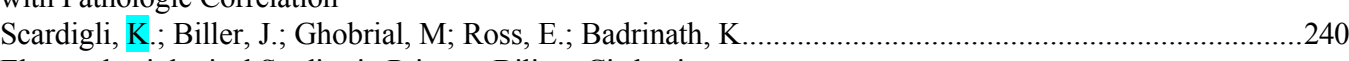

Electrophysiological Studies in Primary Biliary Cirrhosis

Zeitlhofer, J.; Mamoli, B; Dragosics, B.; Knoflach, P

Electrooculography in at-Risk Subjects for Huntington's Disease

Valade, D; Davous, P.; Rondht, P.

Fahr's Disease Associated with Cystic Astrocytoma

Morimoto, $\mathrm{K}$;

Chronic Haloperidol Administration

Striatum without Altering the Glutamate Leve

Kornhuber, J.; Kim, J.S.; Kornhuber, M.E.; Kornhuber, H.H

Hemangiopericytic Meningioma of the Pineal Region. Case Report

Bruyn, G.W.; Padberg, G

Cerebrospinal Fluid Prostaglandin F2, in Stroke Patients: No Relationship to the Degree of

Neurological Deficit

Kostic, V.S.; Djuricic, B.M.; Mrsulja, B.B

A Childhood Form of Huntington's Disease Associated with Marked Pyramidal Signs

Katafuchi, Y ; Fujimoto, T.; Ono, E.; Kuda, N . . .........296

Cimetidinc Neurotoxicity. EEG and Behaviour Aspects

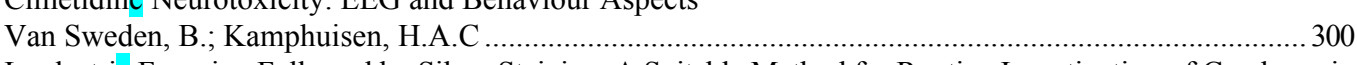

Isoelectric Focusing Followed by Silver Staining. A Suitable Method for Routine Investigation of Cerebrospinal Fluid Proteins

Wikkelso, C; Andersson, M.; Andersson, R.; Blomstrand, C... 
Cellular Localization of Binding Sites for ${ }^{3} \mathrm{H}-\mathrm{DSIP}$ on Neurones of Cultured Rat Brain

Stem

Hosli, E.; Schoenenberger, G.A.; Hosli, L

VI

Contents

\section{Characterization, Properties and Multivariate Functions of Dclta-Sleep-Inducing Peptide}

(DSIP)

Schoenenberger, G.A

Some Pharmacological Effects of Delta-Slcep-Inducing Peptide (DSIP)

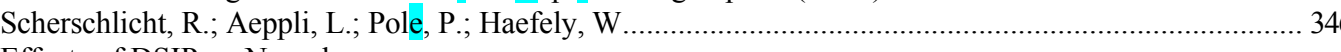

Effects of DSIP on Narcolepsy

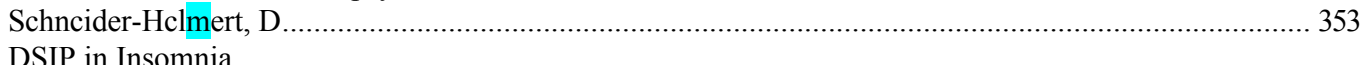

DSIP in Insomnia

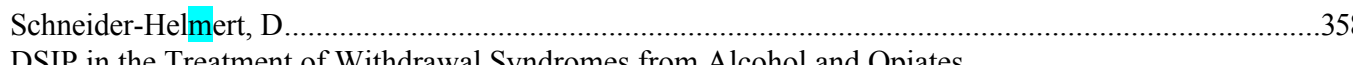

DSIP in the Treatment of Withdrawal Syndromes from Alcohol and Opiates

Dick, P.; Costa, C; Fayolle, K.; Grandjean, M.E.; Khoshbeen, A.; Tissot, R .............................................. 364

Therapeutic Effects of Delta-Sleep-Inducing Peptide (DSIP) in Patients with Chronic, Pronounced Pain Episodes. A Clinical Pilot Study

Larbig, W.; Gerber, W.D.; Kluck, M.; Schoenenberger, G.A …………........................................................

A Clinical Trial with DSIP

Kacser, H.E

No. 6 Vasculitis: Immunological Aspects

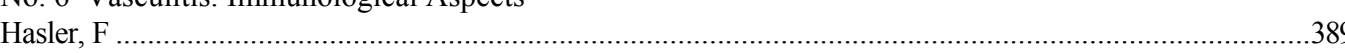

New Aspects of Thromboangiitis obliterans (von Winiwarter-Buerger's Disease)

Berlit, P.; Kessler, C; Reuther, R.; Krause, K.-H

Cerebral Angiography in Vasculitis Affecting the Nervous System

Kendall, B

Cytostatic Drugs in the Treatment of Severe Vasculitides. Indications, Results and Risks

Kaeser, H.E

Gerber, N.J

Stroke in Childhood and Adolescence

Isler, W.

Centronuclear Myopathy with Special Consideration of the Adult Form

Goebel, H.H.; Meinck, H.M.; Reinecke, M.; Schimrigk, K; Mielke, U.

Chorea and Systemic Lupus erythematosus. A Critical Review

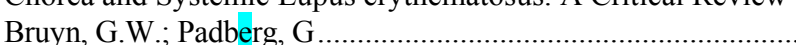

Maturation of the Blink Reflex in Infants

Vecchierini-Blineau, M.F.; Guiheneuc, P

Sarcoidosis of the Peripheral Nerve: Clinical, Electrophysiological and Histological Study of

Two Cases

Galassi, G.; Gibertoni, M.; Mancini, A.; Nemni, R.; Volpi, G.; Merelli, E.; Vacca, G. . 459 How Specific Are Periodic Complexes in the Diagnosis of Herpes simplex Encephalitis?

Roches, J.C.; Probst, A.; Scollo-Lavizzari, G .......................................................................................... 466

Vasculitis in the Central Nervous System - Contribution of Angiography

Kendall, B ...

Meige's Syndrome: Acute and Chronic Responses to Clonazepan and Anticholinergics

Hipola, D.; Mateo, D.; Gimenez-Roldan, S

Motor Dysfunction following Chronic Exposure to a Fluoroalkane Solvent Mixture Containing Nitromethane

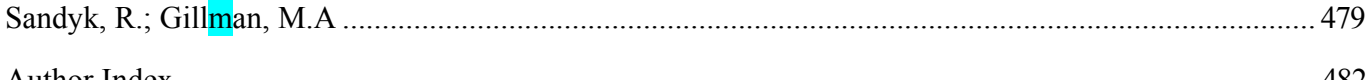

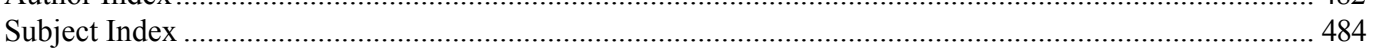

